
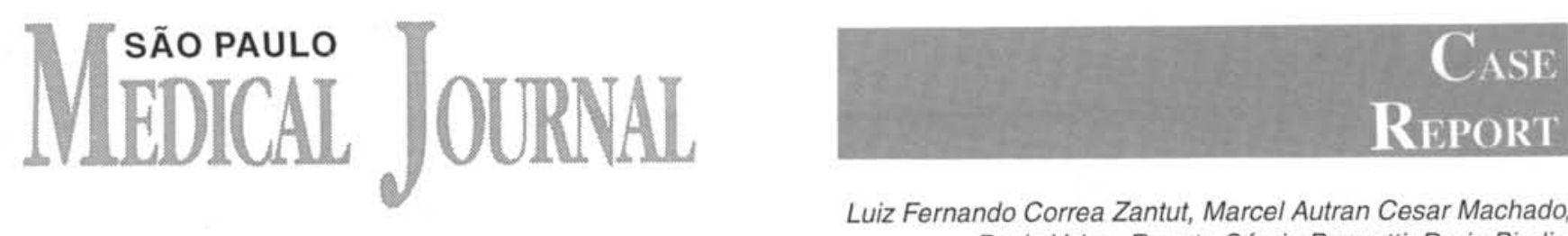

Luiz Fernando Correa Zantut, Marcel Autran Cesar Machado, Paula Volpe, Renato Sérgio Poggetti, Dario Birolini

\title{
Extrahepatic bile ducts injury: a report on 14 cases
}

Disciplina de Cirurgia do Trauma da Faculdade de Medicina da Universidade de São Paulo - São Paulo, Brazil

\begin{abstract}
Traumatic injuries of the extrahepatic biliary tract are infrequent, occurring in approximately $0.5 \%$ of all patients with blunt and penetrating abdominal trauma. The incidence of this injury due to blunt abdominal trauma is rare. This study reviewed patients with injuries of the extrahepatic biliary tract due to abdominal trauma over a 6-year period to determine the incidence, trauma scores, associated injuries, surgical treatment performed, complications and mortality rate. We report our experience with 14 patients with extrahepatic biliary tract trauma. A review of the literature and the discussion about the management are presented.
\end{abstract}

UNITERMS: Extrahepatic biliary tract, Injury, Abdominal trauma.

\section{INTRODUCTION}

$\mathrm{T}$ raumatic injuries to the extrahepatic bile ducts remain relatively rare even in the busiest trauma centers. Formerly, blunt trauma to the right upper quadrant accounted for most of the reported injuries to the bile ducts, but in recent years, penetrating trauma has been the most common cause. Because of the variable complexity of injuries, a wide variety of surgical options for repair of the bile ducts is possible. We report, herein, on our experience with patients who sustained traumatic injuries to the extrahepatic bile ducts over a six-year period.

\section{MATERIALS AND METHODS}

During the 6-year period from 1986 to $1991,5,069$ patients underwent laparotomy for abdominal trauma at the Department of Surgery, University of São Paulo School of Medicine, Brazil. Eighteen patients $(0.35 \%)$ had injuries involving the extrahepatic bile ducts. Records, including

\author{
Address for correspondence: \\ Luiz Fernando Correa Zantut \\ Av. Brig. Luis Antonio, 4521 - Jd. Paulista \\ São Paulo/SP - Brasil - CEP 01401-002
}

operative and pathology reports, were reviewed to study the site of injury, associated intra-abdominal injuries, incidence, trauma scores, type of repair, morbidity and mortality rates.

\section{RESULTS}

Eighteen patients with extrahepatic bile ducts injuries were identified in a group of 5,069 patients $(0.35 \%)$ who sustained intra-abdominal trauma over a six-year period. The patients age ranged from 15 to 30 years with a mean age of 22.5 years; 17 of the 18 patients were male.

Of the 18 extrahepatic bile ducts injuries, $15(83.3 \%)$ were caused by penetrating wounds, and three by blunt trauma. All patients underwent exploratory laparotomy. In the 18 patients, 63 intra-abdominal injuries were found, or 3.5 per patient. Thirteen of the 18 patients $(72.2 \%)$ had lacerations of the liver. Pancreas lacerations (11 patients), gastric lacerations (6 patients) and duodenal lacerations ( 6 patients) were the next most commonly seen injuries (Table.1). The distribution of injuries to the extrahepatic bile ducts was as follows: the left hepatic duct in one patient, the common hepatic duct junction in one patient, the common hepatic duct in three patients, the cystic duct in one patient and distal common bile duct or ampulla of Vater in 12 patients (Fig.1). Five of the 18 patients died (27.7\%), none as a result of their bile duct injury. Two of these patients had simple lateral repairs, one of whom underwent decompression with a $\mathrm{T}$ tube. Five patients with simple repairs survived, and none had 
problems related to the repair of the bile tract at the time of discharge. Two of ten patients with complex repairs died in the hospital. Six patients with an intrapancreatic common bile duct injury underwent a duodenopancreatectomy. Two patients with a complete transection of the common hepatic duct and common hepatic duct junction underwent Roux-en-Y hepaticojejunostomy. One patient with distal common bile duct lesion underwent Roux-en-Y choledochojejunostomy. One patient with distal common bile duct injury underwent choledochoduodenostomy (Table 2).

\section{Table 1}

Associated Intra-Abdominal lesion in patients with extrahepatic biliary ducts injuries

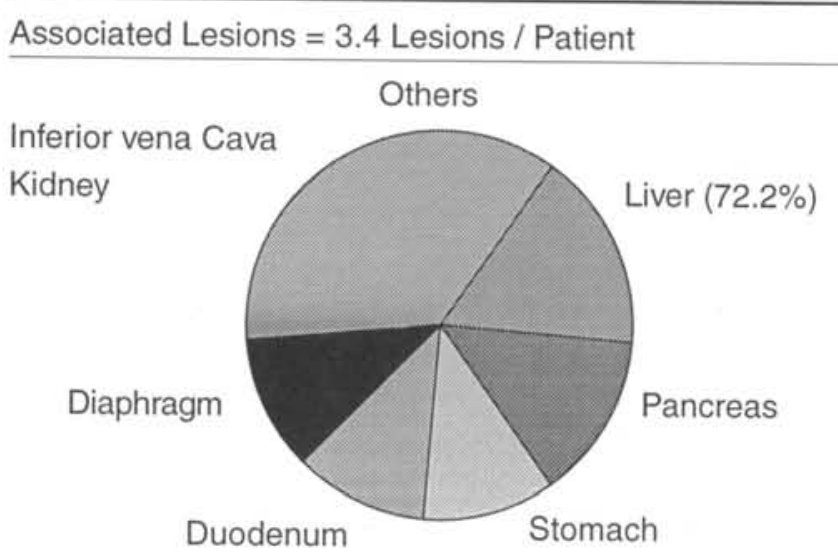

\section{DISCUSSION}

Trauma to the extrahepatic bile ducts is a rare but insidious diagnostic problem which is potentially fatal. Increasing civilian violence and a greater frequency of motor vehicle accidents are resulting in a higher incidence of trauma to the extrahepatic biliary system. Injury to the ducts themselves is rarely fatal, however associated injuries result in significant mortality. Furthermore, bile tract injuries themselves can be associated with considerable morbidity such as bilestenosis and leakage. Extrahepatic bile tree injury due to blunt abdominal trauma is rarer than penetrating injury. In the present series, the incidence was $0.12 \%$ and $0.57 \%$, respectively.

The clinical picture is variable. Initially, there could be shock with severe or moderate low blood pressure, accompanied by considerable upper abdominal pain and rigidness, usually most severe in the right upper quadrant. Usually the period of shock and pain is a matter of few hours or less, and is followed by relatively symptom-free interval, unless there are associated injuries. With leakage of bile into the peritoneal cavity, jaundice, bileascites and acholic stools occur. The jaundice is due to the absorption of bile pigment by the peritoneum.

Extrahepatic bile duct injuries are usually detected at the time of laparotomy and are seldom diagnosed preoperatively. Even during celiotomy, these lesions may

Table 2

Surgical Procedures

Treatment

\begin{tabular}{ll} 
Suture & 3 \\
Pancreaticoduodenectomy & 3 \\
Suture + Choledochostomy & 2 \\
Choledochostomy & 2 \\
Hepaticojejunostomy Roux-en-Y & 2 \\
Choledochojejunostomy Roux-en-Y & 1 \\
Cholecystectomy & 1 \\
\hline
\end{tabular}

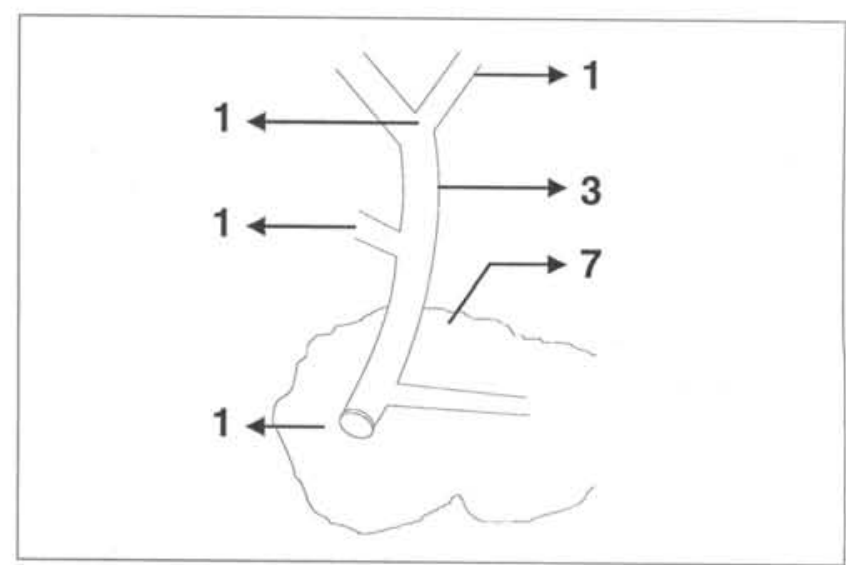

Figure 1 - Distribution of lesions in extrahepatic biliary ducts

be missed unless the bile tract is carefully inspected, a process which is more likely to be omitted in the presence of life-threatening wounds. Intra-operative cholangiography is extremely helpful in making the diagnosis of bile duct injury and in accurately localizing the injury.

Management of patients with traumatic extrahepatic lesions of the bile tract depends upon the site, type of injury and general conditions of the patient. In the profoundly hypotensive patient with a partial tear, external drainage will prevent bileascites and may occasionally be curative, although the formation of a stricture often occurs. On occasion, a small perforation or tear may be present in the retro-panreatic portion of the common bile duct. In the unstable patient or the stable patient in whom visualization is difficult, another alternative is the insertion of a proximal tube to decrease the output from the expected fistula. If the patient is stable and has a partial tear, cystic duct 
avulsion, or small through injury, a primary repair with an absorbable suture can be performed.

If the transection is clean and simple without significant contusion of both ends of the duct, an end-to-end anastomosis may be utilized. Dissection around the duct will cause additional devascularization of the ends, and should be avoided. When tension is present at the anastomosis, a stricture will result. When a complex transection has occurred, or a portion of the common bile duct has been destroyed or devascularized in a stable patient, a bilioenteric anastomosis using a Roux-en-Y limb should be performed.
On occasion, the combination of a hepatic ductal injury and a parenchymal injury will lead to a hepatic lobectomy. Duodenopancreatectomy is best reserved for rare distal bile duct injuries combined with injuries to the pancreatoduodenal complex or ampulla of Vater, as occurred in three of our patients.

We concluded that the type of repair employed in our series was related to the hemodynamic stability and clinical conditions (based on trauma scores) of the patient more than to the site and complexity of the injury.

\section{RESUMO}

As lesōes das vias biliares extra-hepáticas sāo condiçōes raras, graves e que possuem variadas formas de apresentaçāo. Foram estudados 5.069 pacientes com traumatismo abdominal, atendidos no Pronto Socorro do Hospital das Clínicas da Faculdade de Medicina da Universidade de Sāo Paulo, no periodo de 1986 a 1991, e identificados 14 deles com lesāo em via biliar extrahepática. Foram analisados os indices de trauma (RTS, ISS eTRISSCAN), sexo, idade, incidência, presença de lesōes associadas, tratamento cirúrgico realizado, evoluçāo pós-operatória, morbidade e mortalidade. Dos 14 pacientes, somente três (21.4\%) tiveram esse tipo de lesão decorrente de trauma abdominal fechado, sendo os demais devido à trauma penetrante. A idade média dos pacientes com lesảo da árvore biliar foi de 23.2 anos. A incidência foi de $0.28 \%$ do total de pacientes e a mortalidade de 21.4\%. O figado e o pâncreas foram os órgãos mais acometidos, seguidos do estômago e duodeno. O tipo de lesão associada foi fator que contribuiu na mortalidade desses pacientes. O sítio mais freqüente de lesão foi o colédoco na sua porção intrapancreática ( $50 \%$ dos casos). Os autores concluiram que o tipo de cirurgia empregado (conservador ou radical) esteve mais relacionado às condiçōes gerais do paciente (dai a importância dos índices de trauma) do que à complexidade das lesōes.

\section{REFERENCES}

1. Bade PG, Thomson SR, Hirshberg A, Robbs JV. Surgical options in traumatic injury to the extrahepatic biliary tract. Br J Surg 1989;76:256.

2. Diethrich EB, Beall AC, Jordan GL, De Bakey ME. Am J Surg 1966;112:756.

3. Feliciano DV, Bitondo CG, Burch JM, Mattox KL, Beall Jr $\mathrm{AC}$, Jordan GL. Management of traumatic injuries to the extrahepatic biliary ducts. Am J Surg 1985;150:705.

4. Manlove CH, Quattlebaum FW, Ambrus L. Non-penetrating trauma to the biliary tract. Am J Surg 1959;97:113.

5. Shorthouse AJ, Singh MP, Treasure T, Franklin RH. Isolated complete transection of the common bile duct by blunt abdominal trauma. Br J Surg 1978;65:543.

6. kitahama A, Elliot LF, Overby JL, Webb WR. The extrahepatic biliary tract injury. Ann Surg 1982;196:536.

7. Longmire WP. Early management of injury of the extrahepatic biliary tract. J Am Med Assoc 1966;195:111.

8. Ivatury RR, Rohman M, Nallathambi M, Rao PM, Gunduz Y, Stahl WM. The morbidity of injuries of the extrahepatic biliary system. J Trauma 1985;25:967.
9. Brickley HD, Kaplan A, Freeark RJ, Broccolo E. Immediate and delayed rupture of the extrahepatic biliary tract following blunt abdominal trauma. Am J Surg 1960;100:107.

10. Mason LB, Sidbury JB, Guiang S. Rupture of the extrahepatic bile ducts from nonpenetrating trauma. Ann Surg 1954;140:234.

11. Hartmann SW, Greaney EM. Traumatic injuries to the biliary system in children. Am J Surg 1964;108:150.

12. Posner MC, Moore EE. Extrahepatic biliary tract injury: operative management plan. J Trauma 1985;25:833

13. Moyle WD, Karl RC. Rupture of the extrahepatic biliary ducts by external blunt trauma. J Trauma 1969;9:623.

14. McFadden PM, Tanner G, Kitahama. Traumatic hepatic injury. Am J Surg 1980;139:268.

15. Estrada RL \& Sutherland NG. Subparietal or non-penetrating traumatic rupture of the biliary tree. Br J Surg 1969;56:7.

16. Zeman RK, Lee CH, Stahl R, et al. Strategy of the use of biliary scintigraphy in non-iatrogenic biliary trauma. Radiology 1984;151:771.

17. Rydell WB. Complete transection of the common bile duct due to blunt abdominal trauma. Arch Surg 1970;100:724.

18. Michelassi F, Ranson JHC. Bile duct disruption by blunt trauma. J Trauma 1985;25:454.

19. Fletcher WS. Non-penetrating trauma of the gallbladder and extrahepatic bile ducts. Surg Clin North Am 1972;52:711.

20. Pailler JL, Auberget JL, Aleya M, Louis P, Mary G. Rupture des voies biliares aucours des traumatismes fermés de l'abdomen. J Chir 1984;121:513. 